\title{
Does Pandemic Covid-19 Affect Foreign Tourist Visit in Jakarta?
}

\author{
Firda Rahmawati*, Nurafni Eltivia, Nur Indah Riwajanti, Hesti Wahyuni \\ Accounting Department \\ State Polytechnic of Malang \\ Malang, Indonesia \\ *firdarahmawati1331@gmail.com,neltivia@gmail.com
}

\begin{abstract}
The purpose of this study is to predict foreign tourists visiting Jakarta. This research uses quantitative data methods. The data of this research is data on foreign tourist visits to Jakarta which were taken from January 2011 to September 2020 from the National Statistical Bureau. The results of the analysis using exponential smoothing with the help of Microsoft Excel show that the forecasting results in the 2021 period will increase by $16 \%$ from the 2020 period due to the spread of the global pandemic, namely Covid-19. this offers optimism for a revival for the tourism sector as well as for other sectors in Jakarta.
\end{abstract}

Keywords—forecasting, exponential smoothing, foreign tourist, Covid-19 pandemic

\section{INTRODUCTION}

Tourism is one of the supports in developing a specific country or region with potential in tourist objects. With the development of a tour, in the end, it can have a positive influence on the country or region, such as the economy increasing so that the surrounding community is more prosperous, facilities are built to make it easier for people, for the example, the construction of the Mass Rapid Transit (MRT) to Soekarno-Hatta Airport with the MRT can make it easier for people from traffic jams in Jakarta. Tourism is a series of activities carried out by groups or individuals to quick visits, not to do work or earn income.

Jakarta is the capital city of Indonesia, which is one of the tourism destinations in Indonesia with tourists from various foreign countries based on data from the National Statistical Bureau Jakarta Provincial 2020, the number of tourist visits from 2 entrances, namely Soekarno-Hatta Airport and Halim Kusuma Airport in the month January to September 2020 with arrivals from various countries such as Malaysia, Saudi Arabia, South Korea, China, America, Singapore, Japan, and others. Jakarta has a tourist attraction by offering cultural tourism and culinary tourism. In 2020, the data on tourist visits have fluctuated in visiting Jakarta, from January to May 2020 experiencing a very significant decline, especially in April 2020 , compared to tourist visits in the previous year, which increased. This is due to the Covid-19 pandemic that has spread throughout the city of Jakarta. Meanwhile, from June to September 2020, tourists passing through Soekarno-Hatta Airport and Perdana Kusuma Airport were recorded to have increased compared to January to May 2020, which sharply decreased. From this description, the purpose of this study is to predict the level of foreign tourist visits to Jakarta in 2021 and in terms of time series data components at Soekarno-Hatta Airport and Halim Perdana Kusuma Airport from January to September 2020.

Based on previous research, Rahmad et al. [1] have examined the forecast of the number of foreign tourist arrivals in 2011 - 2016 using the time-invariant fuzzy time series method. The analysis results at tourist attractions in the Pasuruan Regency area show that testing the accuracy of forecasting using the Fuzzy Time series method is not suitable for predicting large amounts of data and the use of unstable data on the fluctuation of the data. The decrease in the number of foreign tourist arrivals caused by Covid-19 could impact the people's economy if it occurs at a constant time. The things that are of concern for the economic aspects of Jakarta are an increase in unemployment, a low inflation rate, a decrease in the welfare of the community,

This research uses a forecasting method to predict the level of foreign tourist visits to Jakarta in the next period, namely in 2021. The reason for choosing Jakarta province is because Jakarta is the capital city, which is the main gateway for tourism in Indonesia. The type of forecasting method used to calculate data is the time series method based on time variables. One of the time series methods, namely Exponential Smoothing, uses data from January to September 2020 to predict the 2021 period.

\section{THEORETICAL REVIEW}

According to Law Number 9 of 1990 [2] everything related to tourism, including the exploitation of tourist objects and associated attractions and businesses in that field. Tourism is a quick transition of places and travels to obtain services from companies engaged in tourism [3]. Tourists are visitors to a country they visit who stay at least 24 hours and come based on spending time for fun or vacation, going on business trips, and 
making visits to see meetings [4]. Tourism is a collection of activities, services, and industries that provide travel experiences, including transportation, accommodation, food and beverage businesses, retail stores, entertainment businesses, activity facilities, and other services provided to individuals and groups who travel long distances. The most important reason for developing tourism in a tourist destination, both locally and internationally in a country is very strong in relation to the development of an area, the development of the regional economy [5]. Therefore, tourism development is always predicted to provide benefits and benefits to the community. Tourism is one of the factors that is growing rapidly in the world [6].

According to Heizer and Render [7] forecasting is a science and art to predict the future using historical data and use it to the end with a systematic approach system. Forecasting foreign tourist arrivals is very important for the purposes of planning, policy making, and budgeting by parties related to tourism [8]. Over the year's various time series models have been successfully applied to predict tourist arrivals [9]. To indicate the level of foreign tourist visits requires a forecast with the right method, namely the Time series model, which is a method of forecasting widely used in various fields. The time series model used is Exponential Smoothing. Exponential smoothing is a method that shows the weight decreases exponentially with the longer observed value. This is the formula of Exponential Smoothing:

- Moving Average

$=$ AVERAGE $(\mathrm{Q} 1: \mathrm{Q} 4)$

- Center Moving Average

$=$ AVERAGE $\left(\mathrm{Yt}_{1}: \mathrm{Yt}_{2}\right)$.

- Seasonality Irregularity

$=\left(\mathrm{Yt}_{1}\right) /$ "CMA"

- Seasonality

$=\left(\mathrm{St}_{1}\right) /$ Average $(\mathrm{Q} 1 ; \mathrm{Q} 4)$

- Deseasonalize

$=\left(\mathrm{Yt}_{1}\right) /\left(\mathrm{St}_{1}\right)$.

- Trend

$=\mathrm{I}+\mathrm{t} * \mathrm{X}$

- Forecast

$=(\mathrm{St}) *(\mathrm{Tt})$
Explanation:

$\begin{array}{rll}\mathrm{Yt} & = & \text { Foreign Tourism } \\ \mathrm{St} & = & \text { Seasonality } \\ \mathrm{Tt} & = & \text { Trend } \\ \mathrm{I} & = & \text { Intercept } \\ t & = & \text { coefficient } \mathrm{t}\end{array}$

\section{METHODS}

The data used is quantitative. This study's data are data on foreign tourist visits to Jakarta, which were taken from January 2011 to September 2020. The data used are secondary. This data can be obtained from the website of the National Statistical Bureau. The variable used to predict is the recapitulation of foreign tourist visits from the two doors of Soekarno-Hatta Airport and Halim Kusuma Airport from 2011 to 2020 .

The analysis method to be projected is Time Series Analysis. The technique used is the Exponential Smoothing method, data obtained from historical data. The data will be processed using the forecasting method (forecasting) to predict the number of foreign tourist visits to Jakarta. To get forecast results with the help of Excel and you can also use formulas. Forecasting the level of foreign tourist visits in terms of trends calculated using time series data with the help of Microsoft Excel, because this software makes it easier to predict the level of foreign tourist visits to DKI Jakarta in the future based on past data [10].

\section{RESULTS AND DISCUSSION}

Actual data on foreign tourist visits to Jakarta were obtained from the National Statistical Bureau from January 2011 to September 2020, with 117 data. Data on the number of foreign tourist arrivals starting from the 1st quarter of 2011 to the 3rd quarter of 2020 can be seen in Figure 1. As seen from Figure 1, the 3rd quarter 2019 to 2nd quarter 2020 experienced a very sharp decline, and the peak of the increase occurred in the 3rd quarter. In the period of 2019 in the 3rd quarter it can be concluded from the graph in Figure 1 that the visit of foreign tourists to Jakarta has experienced a very significant downward trend due to the global pandemic that has spread throughout the world which also affects the Indonesian capital, Jakarta. Therefore, as a result of the global pandemic or the Covid-19 pandemic in the city of Jakarta, it is necessary to forecast foreign tourist visits in the 2021 period using the Exponential smoothing method. 


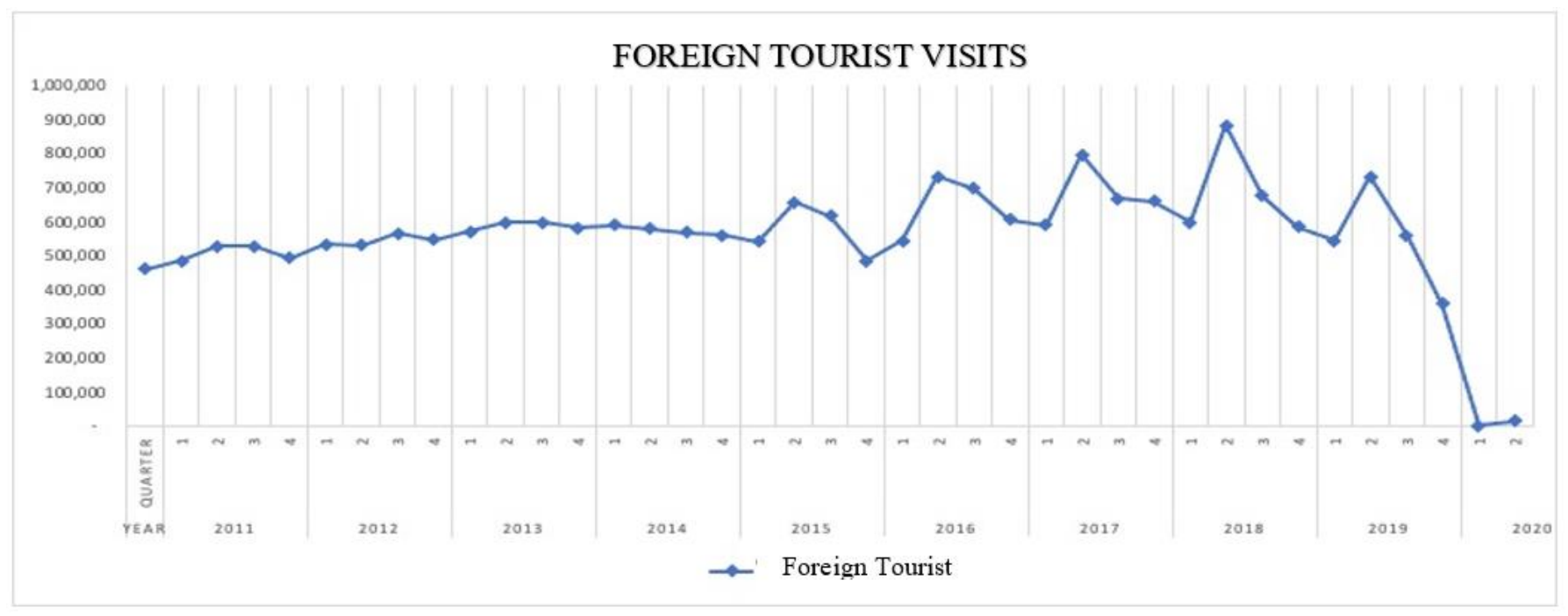

Source: National Statistical Bureau

Fig. 1. Graph of foreign tourist visit to DKI Jakarta.

Forecasting results using the Exponential Smoothing method with Microsoft Excel's help, foreign tourist visits to Jakarta in the 4th quarter of 2020 have decreased until the 2nd quarter of 2021 can be seen in Table 2. From Table 2, it can be seen that forecasting of the number of foreign tourist visits to Jakarta amounting to 67,368 in the 4th quarter of 2020 which decreased from the 3rd quarter, then in the 1st quarter of 2021 there was a decrease of 96,567, in the 2nd quarter of 2021 it decreased very sharply by 153,789 . Meanwhile, in the third quarter of 2021, there was an increase of 244,917; in the fourth quarter of 2021, the forecast decreased by 390,043 .

Since the spread of the Covid-19 virus that hit the world including the city of Jakarta, the trend of foreign tourists to Jakarta has decreased very significantly, this has had a heavy impact, especially on the tourism sector, which suffered a considerable loss. The government has issued a new regulation for tourists who want to visit Jakarta, which is to carry out a rapid Antigen test which is worth IDR 250000.With this regulation, many tourists do refund tickets and this also has an impact on the trend of tourist visits of foreign tourists. So far, the tourism sector's contribution is one of the state's financial revenues. If seen from Table 2 , the decline began to occur in the first quarter of 2020 because domestic and international flights have been closed since the fourth quarter of 2019 and travel agents are one of the ones that have a direct impact due to the Covid-19 pandemic, which many have canceled travel plans. had been scheduled from the previous day. The economic sector in Jakarta has also experienced the impact of Covid-19, namely foreign exchange earnings have decreased quite significantly. However, the Trend Forecast in the 4th quarter of 2021 has increased by $16 \%$. This increase can occur when airlines operate and the Jakarta government opens tourist spots but by implementing and adhering to established health protocols.
TABLE I. FORECASTING OF FOREIGN TOURIST VISITS TO DKI JAKARTA

\begin{tabular}{|c|c|c|c|c|c|}
\hline No. & Year & $\mathbf{Q}$ & $\begin{array}{l}\text { Foreign } \\
\text { tourists }\end{array}$ & $\begin{array}{l}\text { Moving } \\
\text { Average }\end{array}$ & Forecast \\
\hline 1 & \multirow{4}{*}{2011} & 1 & 461,217 & & 408,190 \\
\hline 2 & & 2 & 485,530 & & 436,958 \\
\hline 3 & & 3 & 529,189 & 500,986 & 484,152 \\
\hline 4 & & 4 & 528,008 & 509,205 & 490,956 \\
\hline 5 & \multirow{4}{*}{2012} & 1 & 494,092 & 521,432 & 466,798 \\
\hline 6 & & 2 & 534,438 & 521,763 & 512,895 \\
\hline 7 & & 3 & 530,514 & 531,378 & 517,051 \\
\hline 8 & & 4 & 566,469 & 544,588 & 560,553 \\
\hline 9 & \multirow{4}{*}{2013} & 1 & 546,929 & 553,923 & 549,384 \\
\hline 10 & & 2 & 571,780 & 570,545 & 582,884 \\
\hline 11 & & 3 & 597,000 & 578,448 & 617,509 \\
\hline 12 & & 4 & 598,083 & 587,434 & 627,560 \\
\hline 13 & \multirow{4}{*}{2014} & 1 & 582,872 & 592,249 & 620,303 \\
\hline 14 & & 2 & 591,039 & 587,531 & 637,820 \\
\hline 15 & & 3 & 578,129 & 579,824 & 632,521 \\
\hline 16 & & 4 & 567,255 & 574,313 & 629,094 \\
\hline 17 & \multirow{4}{*}{2015} & 1 & 560,829 & 561,927 & 630,342 \\
\hline 18 & & 2 & 541,493 & 581,578 & 616,695 \\
\hline 19 & & 3 & 656,735 & 594,307 & 757,749 \\
\hline 20 & & 4 & 618,169 & 575,402 & 722,482 \\
\hline 21 & \multirow{4}{*}{2016} & 1 & 485,209 & 575,847 & 574,331 \\
\hline 22 & & 2 & 543,274 & 594,984 & 651,173 \\
\hline 23 & & 3 & 733,282 & 614,501 & 889,868 \\
\hline 24 & & 4 & 696,240 & 644,411 & 855,313 \\
\hline 25 & \multirow{4}{*}{2017} & 1 & 604,846 & 656,000 & 752,069 \\
\hline 26 & & 2 & 589,632 & 671,918 & 741,957 \\
\hline 27 & & 3 & 796,953 & 664,514 & $1,014,737$ \\
\hline 28 & & 4 & 666,624 & 678,057 & 858,747 \\
\hline 29 & \multirow{4}{*}{2018} & 1 & 659,019 & 679,961 & 858,791 \\
\hline 30 & & 2 & 597,246 & 701,239 & 787,211 \\
\hline 31 & & 3 & 882,065 & 703,806 & $1,175,793$ \\
\hline 32 & & 4 & 676,894 & 685,506 & 912,408 \\
\hline 33 & \multirow{4}{*}{2019} & 1 & 585,820 & 672,202 & 798,394 \\
\hline 34 & & 2 & 544,028 & 634,504 & 749,561 \\
\hline 35 & & 3 & 731,272 & 605,281 & $1,018,465$ \\
\hline 36 & & 4 & 560,004 & 548,219 & 788,297 \\
\hline 37 & \multirow{4}{*}{2020} & 1 & 357,572 & 412,653 & 508,680 \\
\hline 38 & & 2 & 1,762 & 233,625 & 2,533 \\
\hline 39 & & 3 & 15,161 & 124,832 & 22,021 \\
\hline 40 & & 4 & & & 67,368 \\
\hline 41 & \multirow{4}{*}{2021} & 1 & & & 96,567 \\
\hline 42 & & 2 & & & 153,789 \\
\hline 43 & & 3 & & & 244,917 \\
\hline 44 & & 4 & & & 390,043 \\
\hline
\end{tabular}

Source: Data Processed, 2020 


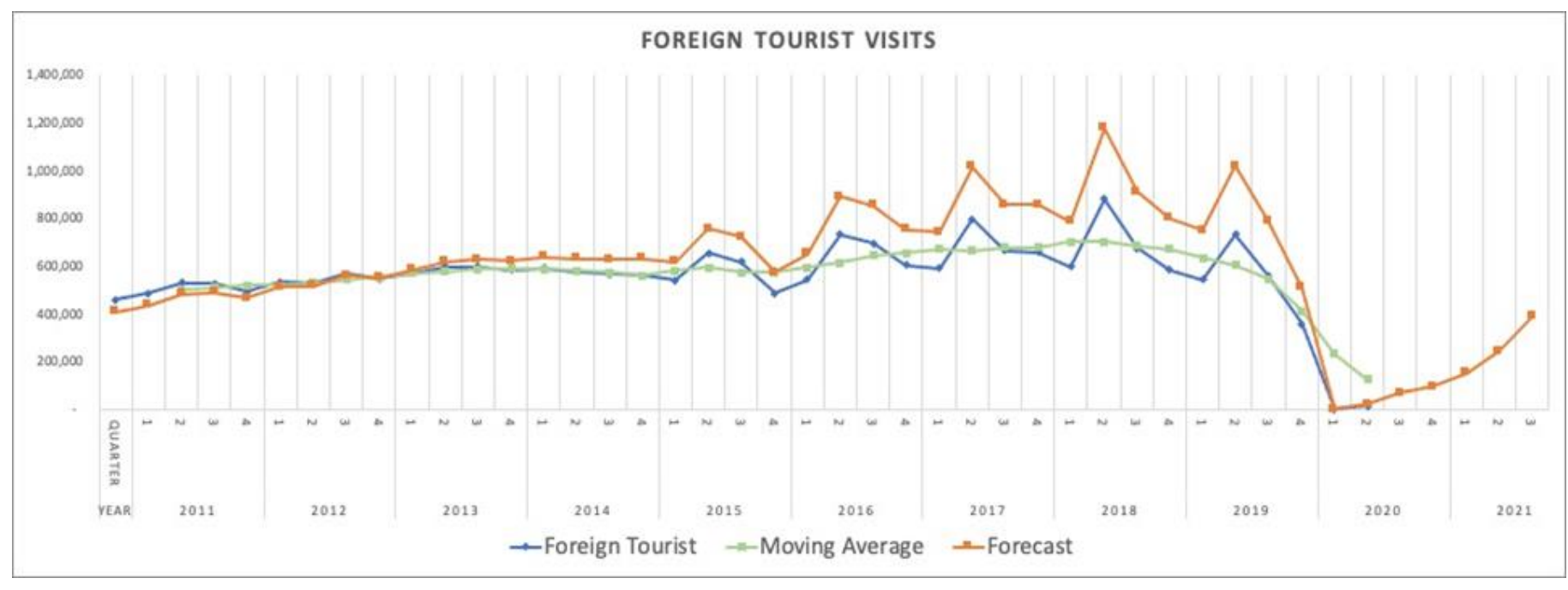

Fig. 2. Forecasting of foreign tourist visits to DKI Jakarta.

\section{CONCLUSION}

With the development of tourism, in the end it can have a positive influence on the country or region, such as the economy increasing so that the surrounding community is more prosperous. Planning for the future and predicting what will happen is essential for success in the tourism sector. Therefore, making accurate forecasts is an important step for this process. Choosing the right forecasting model can avoid financial losses. In the third quarter of 2020, there was the spread of the covid-19 virus that hit the world, one of which is the city of Jakarta, with the impact of this pandemic causing a very sharp decline in the tourism sector, especially in travel agencies which first experienced the impact of this virus which cancellation of tourist trips and the Jakarta government closing 2 main doors, namely Soekarno-Hatta Airport and Halim Perdana Kusuma Airport.

This study uses the Exponential Smoothing method with Microsoft Excel to predict foreign tourist visits to Jakarta. The number of foreign tourists visiting Jakarta in the following year has increased and decreased. This is due to the pandemic that occurred in Jakarta so that it is different from predictions.

The Exponential Smoothing method is suitable for shortterm forecasting. However, for more accurate forecasting results, long-term forecasting can be done using other methods such as ARIMA.

\section{REFERENCES}

[1] C. Rahmad, M. Ramadhani, and D. Puspitasari, "Forecasting the number of foreign tourist arrivals using the Time Invariant Fuzzy Time Series method (Case study: Pasuruan Regency Tourism)," Journal of Polinema Informatics, vol. 4, no. 3, p. 195, 2018.

[2] Law Number 9 of 1990 concerning Tourism

[3] Musanef, Management of tourism businesses in Indonesia. Jakarta: Mount Agung, 1995.

[4] R. Soekadijo, Anatomy of tourism. Jakarta: Gramedia Pustaka Utama, 2000.

[5] K.M.U.B. Konarasinghe, "Forecasting Tourist Arrivals to Sri Lanka: Post-War Period," vol. 3, no. 1, pp. 57-63, 2016.

[6] O. Yoeti, Introduction to Tourism Science (Edition 1). Yogyakarta: Erlangga, 1995.

[7] J. Heizer and B. Render, Operations Management Sustainability and Supply Chain Management Eleventh Edition. United States: Pearson Education, Inc, 2011.

[8] C. Trihendradi, IMB SPSS 21 Statistical Data Analysis. Yogyakarta: ANDI Yogyakarta, 2013.

[9] H. Hassani, A. Webster, E. Silva, and S. Heravi, "Forecasting U.S. Tourist arrivals using optimal Singular Spectrum Analysis," Tourism Management, vol. 46, pp. 322-335, 2015.

[10] F. Rahmawati, N. Eltivia, and K. Susilowati, "Forecasting the Arrival of Indonesian Foreign Tourists: Holt's Winter Exponential Smoothing Method," Mahardhika media, vol. 18, no. 2, p. 233, 2020. 